\title{
MYTH OR REALITY? UNVEILING THE EFFECTIVENESS OF HIERARCHICAL CEO SUCCESSION ON FIRM PERFORMANCE AND CASH HOLDINGS
}

\author{
Muddassar SARFRAZ (D)1, Bin $\mathrm{HE}^{2}$, Syed Ghulam Meran SHAH ${ }^{\left({ }^{*}\right.}{ }^{*}$, \\ Zeeshan FAREED (D) 4 \\ ${ }^{1}$ Binjiang College, Nanjing University of Information Science and Technology, Wuxi, \\ Jiangsu, PR China \\ ${ }^{2}$ School of Management, Guangdong University of Technology, \\ Guangzhou, PR China \\ ${ }^{3}$ School of Business Administration, South western University of Finance and Economics, \\ Chengdu, PR China \\ ${ }^{4}$ School of Business, Huzhou University, Huzhou City, \\ Zhejiang Province, PR China
}

Received 30 September 2019; accepted 22 May 2020

\begin{abstract}
The objective of the study is to contemplate the effectiveness of hierarchical CEO succession and hierarchical CEO succession intensity on SOEs \& Non-SOEs performance separately. Meanwhile, the impact of hierarchical CEO succession on cash holdings has also been analysed. The authenticated data has been accumulated from CSMAR for the years 2012-2016 contemplating the listed companies (SOE and Non-SOEs separately for performance while overall companies for cash holdings) on Shenzhen and Shanghai stock exchanges. Through categorization of hierarchical CEO succession, it has been signified that middle-level hierarchical CEO succession elevates the SOEs performance. In contrast, middle and high-level hierarchical $\mathrm{CEO}$ succession mitigate the cash holdings. Conclusively, earning management as a moderator has been analysed while deducing that hierarchical CEO succession reduces cash holdings despite firms involving earning management activity which is ultimately beneficial for firms' growth. The empirical results are robust to alternate technique 2SLS instrumental regression that controls for endogeneity.
\end{abstract}

Keywords: corporate governance, hierarchical CEO succession, hierarchical CEO succession intensity, firm performance, cash holdings, earning management.

JEL Classification: G30, G32, G34.

${ }^{\star}$ Corresponding author. E-mail: ghulam_meeran2001@yahoo.co.in 


\section{Introduction}

Corporate governance is highly significant to synchronize the organizational resources for attaining the destined objectives (Iqbal et al., 2019) either through competitive advantage or to maintaining sustainability. Specifically, through the vigilant role of CEO, corporate governance can attain the desired goals. Doubtlessly, every CEO has to depart either via regular or irregular succession. CEO succession is an inevitable phenomenon among the life span of organization which has specific pros and cons. However, the specific attributes of an incumbent CEO do influence the organizational performance (Page, 2018; Li et al., 2020). Relevantly, even board reforms substantiate positive relation with the firms' performance ${ }^{1}$ (Fauver et al., 2017) but the impact of incumbent CEOs via hierarchical disturbance on SOEs and Non-SOEs performance still requires exploration.

Distinguishably, there is less literature witnessing the impact of CEO turnover on cash holdings. Deliberately, firms indulge in cash holdings for the purpose of future investment, but there are specific organizations which are being blamed for utilizing this fund in agency cost (Dittmar et al., 2003; Harford et al., 2008). On contrary, reduction in cash holdings has been witnessed among political connected firms (Xu et al., 2016; Kusnadi, 2019).

Significantly, Chinese organizations have been endorsed due to specific reasons. Firstly, China is being a fast-growing economy, which is a paradigm for other emerging economies. Secondly, Chinese organizations are the amalgamation of SOEs and non-SOEs with distinct characteristics. SOEs are controlled by the government, while non-SOEs are private firms (mostly family-owned firms) (Jiang et al., 2013). Allegedly, in China, the role of CEOs among state-owned enterprises is being criticized due to lack of independence under the strict surveillance of government (Wong, 2016). Despite that, Chinese organizations are performing splendidly. The reason behind this is the renewable Chinese corporate mechanism which has been ameliorating since last few decades, but the intervention of government among SOEs still exists to some extent. That is why the CEOs of SOEs are compelled to perform diligently; otherwise, their early departure is confirmed.

Consequently, the intensity of non-routine CEOs succession is high among SOEs as compared to non-SOEs whenever performance is decelerated (Hu \& Leung, 2012). In contrast, CEO succession among SOEs (by replacing outsider CEOs) is a blessing in disguise while boosting the performance (Jiang et al., 2013). Moreover, among SOEs, it has also been examined that gender change during CEOs succession causes asymmetrical effects on performance (Zhang \& Qu, 2016). Additionally, the effectiveness of gender difference among CEOs on the decision of cash holdings has also been substantiated empirically (Zeng \& Wang, 2015).

Prior research on corporate governance has not only contemplated the influence of CEOs but also accentuated the significance of hierarchy. In this regard, it has been elucidated that hierarchy among board members act as a catalyst for firms' growth (He \& Huang, 2011). In the Chinese perspective, board hierarchy signifies the authority and power which boost the firms' performance via decision making (Zhu et al., 2016). So, it would be worthwhile to investigate the impact of CEOs appointed via hierarchical disturbance on firms' performance

\footnotetext{
${ }^{1} \mathrm{Xu}$ et al. (2016) have identified the impact of CEO turnover on Chinses firms' performance while relying on governmental intervention, developed legal institution and greater market development.
} 
and cash holdings. Hierarchical CEO succession has been formulated through analyzing the hierarchical positioning of board members. In this regards, the companies' profile has been contemplated. After the confirmation of the internal succession, the dummy variable of hierarchical CEO succession has been formulated, which has been further categorized into three levels.

Though abundant literature is replete with the aftermath of CEO succession, still hierarchical CEO succession requires contemplation. In recent studies (Shah et al., 2019b; Sarfraz et al., 2019) have examined the impacts of hierarchical jumps on performance, agency cost and innovation. Though Shah et al. (2019a) have also examined the impact of two types of hierarchical jumps on performance but they have neglected to contemplate whether CEO appointed hierarchical jumps influences the cash holdings or not? Firms endeavor to manipulate through earnings management which should also be analyzed under the aegis of hierarchical successor. Argumentatively, cash holdings and earnings management are quite significant for the future growth of the firms. Unquestionably, splendid corporate governance mechanism endeavor to concentrate on firms 'cash holdings and earnings management which is why this study elucidates the effectiveness of hierarchical CEO succession on cash holdings and demonstrates the role earnings management as a moderator.

The current study has further contributed to the existing literature in five ways. Firstly, the data has been examined for all listed firms for the years (2012-2016) and extended the corporate governance theory by introducing the concept of hierarchical CEO succession for SOEs and non-SOEs separately. Secondly, the impact of hierarchical intensity for both SOEs and non-SOEs performance have been contemplated empirically. Thirdly, the effectiveness of hierarchical CEO succession (HCS) on cash holdings have been analyzed. Fourthly, the impacts of different types of hierarchical CEO succession (low, middle/medium, high) have been analyzed on firms' performance and cash holdings. Fifthly, it has also been demonstrated whether the interaction term of earning management and HCS mitigate the cash holdings or not? Lastly, 2SLS instrumental regression has been executed which authenticates the robustness and reliability of empirical results.

The remnant of the paper proceeds as follow. Next section signifies theoretical background and hypothesis development to elucidate the prior study interlinking with the current study. Data collection, empirical models and measures for the independent, dependent and control variables is illustrated at the end of theoretical background section. Then, methodology and empirical results are explained followed by the discussion. The last section focuses on the conclusion, practical implications and study limitations.

\section{Theoretical background and hypothesis development}

Corporate governance escalates the firms' performance emphatically, but some studies have contemplated that CEO succession can be detrimental to the firms' performance. Reciprocally, Zhang and Qu (2016) have revealed that CEO succession does not deter firms' performance if particular gender change is occurred. Categorically, the forceful turnover signifies the poor performance of firms. In this regard, Hu and Leung (2012) have witnessed the excessive amount of forceful turnover has been observed among SOEs rather than Non- 
SOEs. Conclusively, in a recent study (Shah et al., 2019a; Sarfraz et al., 2019) have concluded that particular type of CEO succession not only enhances the firms' performance but also mitigates the agency cost. However, they haven't contemplated the influence of hierarchical CEO succession on SOEs and Non-SOEs performance separately.

Arguably, hierarchical CEO succession and, the specific type of hierarchical CEO succession (HCS intensity) should influence the SOEs performance absolutely. Theoretically, the idea mentioned above can be contemplated under the rubric of upper echelon theory. Intuitively, upper echelon theory is interlinked with the behavioral theory, which emphasizes that managerial decisions are not always based on logic because of individual bounded rationality (Cyert \& March, 1963). In this regard, being a human, mangers' decisions can suffer from erroneous assumptions due to their psychological factors. Hambrick and Mason (1984), enunciated that demographic factors can demonstrate the executive personality through which his or her preferences can be determined. Significantly, it has already been demonstrated that upper echelon demographics do influence the firms' performance. Most significantly, it has already been examined that among board members, there exist talented individual directors whenever replaced through forceful turnover, firms' performance will not be disrupted (Mobbs, 2013).

Empirically, it has been already assessed that middle-level hierarchical jumps in CEO succession not only boost the firms' performance but also mitigate the agency cost (Shah et al., 2019a). Among Chinese firms (including non-SOEs), CEOs are political connected (Wu et al., 2018) who are desirous to be compensated through government policies. Furthermore, during political uncertainty, firms endeavour to reduce their cash holdings (Xu et al., 2016). Additionally, some study has witnessed that cash holdings for the self-benefits of CEOs lead to augment the agency cost problem (Xu \& Li, 2018). However, CEO succession via hierarchical jumps reduces the agency cost (Shah et al., 2019a). Meanwhile, Jebran et al. (2019) have contemplated that agency cost, and cash holdings are positively interlinked among Chinese firms.

Argumentatively, it can be encapsulated that hierarchical CEO successor should also deter the cash holdings. Though, the current study (Atif et al., 2019) has revealed that board diversity mitigates the cash holdings but has ignored whether hierarchical CEO succession influences the cash holdings reciprocally or not? (Shah et al., 2019a) have signified that medium and high hierarchical jumps in CEO succession are beneficial for firms' performance while mitigating the agency cost. Hence, it represents that hierarchical CEO successor prefers those steps which are ultimately beneficial for firms' performance. Though extant literature has demonstrated the pros and cons of CEO succession on cash holdings (Intintoli \& Kahle, 2016) but neglected the specific type of CEO succession which influence the SOEs firms' performance and cash holdings. It can be assessed that medium and high hierarchical CEO succession must mitigate the cash holdings. To encapsulate, the incumbent CEOs via middle/ medium hierarchical succession endeavor to improve the firms' growth, specifically SOEs, and ultimately deter the cash holdings. Henceforth, the ultimate hypotheses can be formulated as follow.

H1a: Hierarchical CEO successions positively affect the SOEs' performance

H1b: Hierarchical CEO successions intensity positively enhance the SOEs' performance 
H1c: Medium/middle hierarchical CEO successions positively enhance the SOEs' performance

H1d: High hierarchical CEO successions positively enhance the SOEs' performance

H2a: Hierarchical CEO successions mitigate the Cash holdings

H2b: Medium/middle hierarchical CEO successions mitigate the Cash holdings

H2c: High hierarchical CEO successions mitigate the Cash holdings

\section{Earning management and cash holdings}

Prior literature has revealed the negative relation between earning management (accruals) and cash holdings (Sun et al., 2011). Chang et al. (2018) have also examined the negative interconnection between real earning management and cash holdings. The absolute purpose of cash holding is to save something for a rainy day while manipulating through earning management, $\mathrm{CEO}$ can enhance his or her compensation decisively. In some cases, it has been observed that earning management does support forceful turnover (Hazarika et al., 2012). Reciprocally, the hierarchical CEO successions escalate the firms' performance and mitigate the agency cost (Shah et al., 2019a). Therefore, hierarchical CEO successors should not manoeuvre through earning management while reducing the cash holdings. Hence, the above discussion encapsulates the following hypothesis.

H3: The interaction term of hierarchical CEO succession and earning management reduces the Cash holdings

\section{Data collection and variable description}

The study analyzes all listed firms on the Shanghai and Shenzhen stock exchanges. CSMAR and WIND data resources (Zhang \& Qu, 2016) have been preferred for data accumulation. Specifically, hierarchical CEO succession has been formulated manually by analyzing the hierarchical order of the board members of each company's profile (Zhu et al., 2016). Further, hierarchical CEO succession has been categorized into the low, middle and high-level following (Shah et al., 2019a; Sarfraz et al., 2019). Additionally, hierarchical CEO succession intensity has also been defined mathematically.

$$
\begin{aligned}
& H_{C S} S_{i, t+1}=L_{H C S} \cup M H C S_{i, t} \cup M H C S_{i, t} ; \\
& \operatorname{LHCS}_{i, t}= \begin{cases}1 & \text { if } I_{s s c}>0, H R P_{i, t-1} \leq U_{L} \\
0 & \text { otherwise }\end{cases} \\
& \operatorname{MHCS}_{i, t}= \begin{cases}1 & \text { if } I_{s s c}>0, U_{L}<H R P_{i, t-1} \leq M_{L} \\
0 & \text { otherwise }\end{cases} \\
& H H C S_{i, t}= \begin{cases}1 & \text { if } I_{s s c}>0, \quad M_{L}<L H R P_{i, t-1} \leq L_{L} \\
0 & \text { otherwise }\end{cases}
\end{aligned}
$$




$$
\operatorname{HCSINT}_{i, t}=\left\{\begin{array}{ll}
\left(\operatorname{THPOS}_{i, t-1} \times \operatorname{TNSBM}_{i, t-1}\right) & \text { if } I_{s s c}>0 \\
0 & \text { otherwise }
\end{array} .\right.
$$

The Equation (1) represents the hierarchical CEO succession " $H C S_{i, t+1}$ " which is the sum of three sub-hierarchical CEO successions. Equation (2), (3), and (4) describe the low, medium, and high hierarchical CEO successions. In equations (2), (3) and (4) $U_{L}, M_{L}$ and $L_{L}$ represent the upper, middle and low level (as these represent the intervals) of hierarchical ladder among board members whereas " $I_{s s c}>0$ " indicates the internal CEO succession has occurred; then hierarchical CEO succession has been formulated. Similarly, " $H R P_{i, t-1}$ " indicates the hierarchical positioning, which has been analyzed to specify the different levels of hierarchical jumps. Moreover, in equation (4) " $M_{L}<L H R P_{i, t-1} \leq L_{L}$ " indicates that high hierarchical jump (greater middle level and among low hierarchical positing) is considered to be " 1 " when a successor is appointed at lower hierarchical order $\left(L_{L}\right)$ ". Equation (5) elaborates the hierarchical CEO succession intensity, which is the interaction term of a total number of hierarchical position (during hierarchical jumps) and the total number of senior board members neglected.

To measure performance, return on assets (ROA) (Li et al., 2020) and return on investment (ROI) has been endorsed as proxies (Daily et al., 2000). Meanwhile, cash holding has been examined via using the proxies $\ln$ Cash (ratio of cash and cash equivalents to net assets) and lnCash2 (ratio of cash to net assets) following Xu et al. (2016). Control variables are total assets, firm age, the total number of employees, number of independent directors and earnings per share, Duality, AGE, Degree following the prior research (He \& Huang, 2011; Jiang et al., 2013; Zhu et al., 2016; Wong \& Chen, 2018). Reasonably, total assets, firms age and number of employees are interlinked with the firms' performance. Similarly, earning per share is an indicator of performance through which stakeholder is get benefitted. Meanwhile, the number of independent directors indicates the efficiency of corporate governance through their vigilant presence. The remaining variables, AGE, Degree and duality are the indicators of CEO attributes (Jarva et al., 2019) which can affect the performance through hierarchical CEO successor. Additionally, following the prior study of Xu et al. (2016), the variables agency cost and ROA have been embedded in the panel regression to capture the impact of HCS on cash holdings. The variable, "Agency cost" has been measured through the proxy of management ratio (Shah et al., 2019a).

\section{Empirical models}

Panel regression technique ${ }^{2}$ has been executed. Fixed effect model has been executed through the confirmation of the Hausman test. Conclusively, the lagged variables regression has been executed to check the reversal causality. After confirmation of the endogeneity problem, 2SLS instrumental regression has been executed. Significantly, “THPOS” (Shah et al., 2019a; Sarfraz et al., 2019) (total number hierarchical positions in the hierarchy of a successor when he or she is appointed via hierarchical CEO succession) has been endorsed as an instrumental variable. Theoretically, this instrumental variable is directly linked with the independent

\footnotetext{
2 SATA software has been endorsed for regressing panel regression and 2SLS instrumental regression. To combine the data "merge command" has been applied whereas "ivregress" command has been executed for 2SLS regression.
} 
variables (hierarchical CEO succession and hierarchical CEO succession intensity) while influencing the firms' performance and cash holdings.

$$
\begin{aligned}
& P F_{i, t}=\alpha_{0 . t}+\alpha_{1 i t} H_{C S} S_{i, t-1}+\alpha_{2 i t} \text { Dual }_{i t}+\alpha_{3 i t} A G E_{i t}+\alpha_{4 i t} \text { Degree }_{i t}+\alpha_{i t} K_{i t}+\varepsilon_{i t} ; \\
& P F_{i, t}=\alpha_{0 . t}+\widetilde{\alpha_{i t}} \Sigma\left(\text { LHCS }_{i, t-1}+\text { MHCS }_{i, t-1}+\text { HHCS }_{i, t-1}\right)+\alpha_{2 i t} \text { Dual }_{i t}+ \\
& \alpha_{3 i t} A G E_{i t}+\alpha_{4 i t} \text { Degree }_{i t}+\beta_{i t} K_{i t}+\varepsilon_{i t} \text {; } \\
& P F_{i, t}=\alpha_{0 . t}+\alpha_{1 i t} \operatorname{HCSINT}_{i t}+\alpha_{2 i t} \text { Dual }_{i t}+\alpha_{3 i t} A G E_{i t}+\alpha_{4 i t} \text { Degree }_{i t}+\alpha_{i t} K_{i t}+\varepsilon_{i t} ; \\
& \operatorname{LnCASH}_{i, t}=\alpha_{0 . t}+\alpha_{1 i t} \mathrm{HCS}_{i, t-1}+\alpha_{2 i t} \mathrm{Dual}_{i t}+\alpha_{3 i t} A G E_{i t}+\alpha_{4 i t} S O E_{i t}+\alpha_{i t} K_{i t}+\varepsilon_{i t} ; \\
& \mathrm{LnCASH}_{i, t}=\alpha_{0 . t}+\widetilde{\alpha_{i t}} \sum\left(\text { LHCS }_{i, t-1}+\mathrm{MHCS}_{i, t-1}+\mathrm{HHCS}_{i, t-1}\right)+\alpha_{2 i t} \text { Dual }_{i t}+ \\
& \alpha_{3 i t} A G E_{i t}+\alpha_{4 i t} S O E_{i t}+\beta_{i t} K_{i t}+\varepsilon_{i t} \\
& \operatorname{LnCASH} 2_{i, t}=\alpha_{0 . t}+\widetilde{\alpha_{i t}} \Sigma\left(\text { LHCS }_{i, t-1}+\text { MHCS }_{i, t-1}+\text { HHCS }_{i, t-1}\right)+\alpha_{2 i t} \text { Dual }_{i t}+ \\
& \alpha_{3 i t} A G E_{i t}+\alpha_{4 i t} S O E_{i t}+\beta_{i t} K_{i t}+\varepsilon_{i t} \text {. }
\end{aligned}
$$

In Equations (6), (7) and (8), the variable “ $K_{i t}$ ” represents control variables. We have regressed the panel regressions (6)-(8) for contemplating the impact of hierarchical CEO succession, its three types and HCSINT on SOEs and non-SOEs performance. Meanwhile, the panel regressions (9)-(12) indicate the impact of HCS, its three types on cash holdings. Specifically, SOE has been embedded in the panel regression as a dummy variable (Sarfraz et al., 2020). Moreover, following Shah et al. (2019a), Agencyl (management ratio) and Agency2 (operational ratio) have also been analyzed in the panel regressions (9)-(12) to contemplate the effect of agency cost on cash holdings.

\section{Empirical results}

Due to authenticity, only the results of 2SLS instrumental regressions have been interpreted directly (Li et al., 2020). Table 1 illustrates the coefficients of correlation among the variables while witnessing no threat of absolute multicollinearity problem. In Table 2, hierarchical CEO successions (HCS) are significant for SOEs, which confirms that the first hypothesis H1a is satisfied but insignificant for non-SOEs which enunciates that hierarchical CEO successions are only beneficial for SOEs. Table 3 indicates the results for categorization of hierarchical CEO successions revealing that medium hierarchical CEO successions are positively significant while satisfying the third hypothesis H1c. Additionally, CEOs age has shown a negative sign which suggests that middle-aged or aged CEOs should be preferred while appointing through hierarchical CEO succession among SOEs. Meanwhile "LNEMP” and "Fage" (number of employees and firm age) are negatively significant which illustrates that the number of employees and matured firms are both detrimental for firms' performance. Reasonably, 
due to the increase in the number of employees can impose extra burden via enhancing the organizational cost. Similarly, owing to attain the zenith of success; the old firms sometimes follow the obsolete strategies which pave their way towards deceleration. Table 4 has evaluated that hierarchical CEO succession intensity is significant for SOEs while insignificant for non-SOEs concluding that in the case of neglecting senior board members, the growth will be meagre. In Table 4, the second hypothesis H1b is also satisfied.

Table 1. Correlation matrix

\begin{tabular}{|l|c|c|c|c|c|c|c|c|c|c|c|}
\hline Variables & EPS & ROA & ROI & LEV & HCS & LEMP & Dual & Fage & Agency & LnCash & LnCash2 \\
\hline EPS & 1.000 & & & & & & & & & & \\
\hline ROA & 0.261 & 1.000 & & & & & & & & & \\
\hline ROI & -0.009 & -0.000 & 1.000 & & & & & & & & \\
\hline LEV & -0.112 & -0.240 & -0.045 & 1.000 & & & & & & & \\
\hline HCS & -0.010 & 0.0071 & 0.018 & 0.0183 & 1.000 & & & & & & \\
\hline LNEMP & 0.057 & -0.028 & -0.077 & 0.137 & -0.006 & 1.000 & & & & & \\
\hline Dual & -0.008 & 0.0019 & 0.038 & -0.098 & -0.011 & -0.1128 & 1.000 & & & & \\
\hline Fage & -0.019 & -0.024 & -0.118 & 0.286 & 0.023 & 0.1962 & -0.176 & 1.000 & & & \\
\hline Agency & -0.001 & -0.000 & 0.004 & -0.004 & -0.006 & -0.0180 & 0.019 & 0.0264 & 1.000 & & \\
\hline LnCash & 0.094 & -0.023 & -0.040 & 0.262 & -0.024 & 0.3891 & -0.129 & 0.2866 & -0.015 & 1.000 & \\
\hline LnCash2 & 0.089 & -0.002 & -0.014 & 0.069 & -0.022 & 0.2832 & -0.066 & 0.1568 & 0.006 & 0.321 & \\
\hline EM & -0.000 & 0.000 & -0.004 & -0.000 & 0.002 & -0.007 & 0.003 & 0.010 & -0.001 & 0.003 & -0.000 \\
\hline
\end{tabular}

Table 1 describes that there is no threat of absolute multicollinearity (As coefficients values of correlation are less than 0.6 ). The maximum coefficient value of correlation is " 0.3891 " between the variables "InCash" and "INEMP" (logarithm of a number of employees) which is also normal.

Table 2. 2sls instrumental regression (hierarchical jumps and SOEs, Non-SOEs performance)

\begin{tabular}{|c|c|c|c|c|}
\hline & (1) & (2) & (3) & (4) \\
\hline \multirow{2}{*}{ VARIABLES } & ROA & ROI & ROA & ROI \\
\hline & SOE & & Non-SOE & \\
\hline \multirow{2}{*}{ HCS } & $0.0487^{\star}$ & $0.127^{\star}$ & -0.00333 & 0.0943 \\
\hline & $(0.0269)$ & $(0.0717)$ & $(0.0161)$ & $(0.0764)$ \\
\hline \multirow{2}{*}{ Fage } & & $-0.00535^{\star * *}$ & $0.000771^{\text {***}}$ & $-0.00684^{* * *}$ \\
\hline & & $(0.00136)$ & $(0.000297)$ & $(0.00140)$ \\
\hline \multirow{2}{*}{ EPS } & $0.0773^{\star * *}$ & -0.0143 & $0.0528^{\star \star \star}$ & 0.000336 \\
\hline & $(0.00385)$ & $(0.0103)$ & $(0.00214)$ & $(0.00981)$ \\
\hline \multirow{2}{*}{ LEV } & $-0.167^{\star * *}$ & -0.0100 & $-0.0827^{\star * \star}$ & -0.0272 \\
\hline & $(0.00840)$ & $(0.0226)$ & $(0.00634)$ & $(0.0292)$ \\
\hline \multirow{2}{*}{ AGE } & $-0.0806^{\star * \star}$ & $-0.119^{*}$ & 0.000747 & -0.122 \\
\hline & $(0.0291)$ & $(0.0482)$ & $(0.0167)$ & $(0.0789)$ \\
\hline
\end{tabular}


End of Table 2

\begin{tabular}{|c|c|c|c|c|}
\hline & (1) & (2) & (3) & (4) \\
\hline \multirow{2}{*}{ LNTA } & 0.000645 & 0.00470 & -0.00156 & -0.00721 \\
\hline & $(0.00207)$ & $(0.00566)$ & $(0.00139)$ & $(0.00667)$ \\
\hline \multirow{2}{*}{ LNEMP } & $-0.00500^{\star *}$ & $-0.0135^{\star \star}$ & -0.00171 & $-0.0141^{\star *}$ \\
\hline & $(0.00233)$ & $(0.00635)$ & $(0.00141)$ & $(0.00643)$ \\
\hline \multirow{2}{*}{ Dual } & 0.00475 & -0.00787 & -0.00381 & 0.0186 \\
\hline & $(0.00755)$ & $(0.0207)$ & $(0.00369)$ & $(0.0172)$ \\
\hline \multirow{2}{*}{ NDIR } & -0.00116 & 0.00393 & 0.000803 & \\
\hline & $(0.00162)$ & $(0.00441)$ & $(0.00102)$ & \\
\hline Industry $_{\text {dummy }}$ & Yes & Yes & Yes & Yes \\
\hline Year $_{\text {dummy }}$ & Yes & Yes & Yes & Yes \\
\hline \multirow{2}{*}{ Constant } & 0.0664 & $0.238^{*}$ & $0.0923^{* * *}$ & $0.511^{\star * *}$ \\
\hline & $(0.0489)$ & $(0.134)$ & $(0.0316)$ & $(0.150)$ \\
\hline Observations & 4,829 & 4,642 & 7,355 & 6,928 \\
\hline R-squared & 0.164 & 0.040 & 0.113 & 0.080 \\
\hline
\end{tabular}

In Table 2, HCS (hierarchical CEO succession) is positively significant while "AGE" (CEO age), and a number of employees (LNEMP) are negatively significant for SOEs. However, Non-SOEs have revealed insignificant results. Moreover, "Firm age" has shown negative significance for both SOEs and Non-SOEs. Similarly, LEV (leverage) has also shown negative significance. Additionally, "NDIR" (the number of directors) and LNTA (logarithm of total assets) are insignificant.

Table 3. 2sls instrumental regression (all types of hierarchical jumps)

\begin{tabular}{|l|c|c|c|c|}
\hline \multirow{3}{*}{ VARIABLES } & $(1)$ & $(2)$ & $(3)$ & $(4)$ \\
\cline { 2 - 5 } & ROA & ROI & ROA & ROI \\
\hline \multirow{2}{*}{ MHCS } & SOE & & Non-SOE & \\
\cline { 2 - 5 } & $0.154^{* * *}$ & $0.213^{*}$ & $1.65 \mathrm{e}-05$ & 0.0315 \\
\hline \multirow{2}{*}{ LHCS } & $(0.0536)$ & $(0.125)$ & $(0.0311)$ & $(0.146)$ \\
\cline { 2 - 5 } & 0.0219 & 0.0740 & -0.000979 & 0.0176 \\
\hline \multirow{3}{*}{ HHCS } & $(0.0203)$ & $(0.0611)$ & $(0.0150)$ & $(0.0694)$ \\
\hline \multirow{2}{*}{ EPS } & 0.00580 & $0.163^{* * *}$ & -0.00607 & $0.132^{\star *}$ \\
\cline { 2 - 5 } & $(0.0205)$ & $(0.0616)$ & $(0.0136)$ & $(0.0630)$ \\
\hline \multirow{2}{*}{ LEV } & $0.0776^{* * *}$ & -0.0126 & $0.0528^{* * *}$ & 0.000342 \\
\hline \multirow{2}{*}{ AGE } & $(0.00385)$ & $(0.0103)$ & $(0.00214)$ & $(0.00982)$ \\
\cline { 2 - 5 } & $-0.167^{* * *}$ & -0.0177 & $-0.0827^{* * *}$ & -0.0269 \\
\hline & $(0.00843)$ & $(0.0226)$ & $(0.00634)$ & $(0.0292)$ \\
\cline { 2 - 5 } & $-0.0750^{* * *}$ & $-0.0959^{*}$ & -0.000456 & -0.0861 \\
\hline
\end{tabular}


End of Table 3

\begin{tabular}{|c|c|c|c|c|}
\hline & (1) & (2) & (3) & (4) \\
\hline \multirow{2}{*}{ Degree } & & -0.0995 & 0.00343 & -0.0449 \\
\hline & & $(0.0649)$ & $(0.0152)$ & $(0.0708)$ \\
\hline \multirow{2}{*}{ LNTA } & 0.000333 & 0.00149 & -0.00156 & -0.00719 \\
\hline & $(0.00209)$ & $(0.00561)$ & $(0.00139)$ & $(0.00667)$ \\
\hline \multirow{2}{*}{ LNEMP } & $-0.00529^{* *}$ & $-0.0157^{\star *}$ & -0.00170 & $-0.0137^{\star *}$ \\
\hline & $(0.00234)$ & $(0.00635)$ & $(0.00142)$ & $(0.00660)$ \\
\hline \multirow{2}{*}{ Dual } & 0.00492 & -0.00712 & -0.00379 & 0.0179 \\
\hline & $(0.00755)$ & $(0.0207)$ & $(0.00369)$ & $(0.0173)$ \\
\hline \multirow{2}{*}{ Fage } & $-0.000818^{*}$ & & $-0.000768^{\star *}$ & $-0.00672^{* * *}$ \\
\hline & $(0.000399)$ & & $(0.000298)$ & $(0.00141)$ \\
\hline \multirow{2}{*}{ NDIR } & -0.00131 & 0.00268 & 0.000796 & -0.00133 \\
\hline & $(0.00162)$ & $(0.00441)$ & $(0.00102)$ & $(0.00483)$ \\
\hline Industry $_{\text {dummy }}$ & YES & YES & YES & YES \\
\hline Year $_{\text {dummy }}$ & YES & YES & YES & YES \\
\hline \multirow{2}{*}{ Constant } & 0.0685 & $0.278^{\star \star}$ & $0.0923^{\star * *}$ & $0.517^{\star \star \star}$ \\
\hline & $(0.0491)$ & $(0.134)$ & $(0.0316)$ & $(0.151)$ \\
\hline Observations & 4,827 & 4,640 & 7,353 & 6,926 \\
\hline R-squared & 0.165 & 0.036 & 0.113 & 0.080 \\
\hline
\end{tabular}

In Table 3, medium hierarchical CEO successions are positively significant (MHCS) while AGE and number of employees are negatively significant for SOEs. Specifically, all three types of hierarchical CEO succession (low hierarchical CEO (LHCS), medium hierarchical CEO succession (MHCS) and high hierarchical CEO succession (HHCS) are insignificant for non-SOEs.

Table 4. 2sls instrumental regression (hierarchical CEO succession intensity, SOEs and Non-SOEs performance)

\begin{tabular}{|l|c|c|c|c|}
\hline \multirow{3}{*}{ VARIABLES } & $(1)$ & $(2)$ & $(3)$ & $(4)$ \\
\cline { 2 - 5 } & ROA & ROI & ROA & ROI \\
\hline \multirow{2}{*}{ HCSINT } & SOE & & Non-SOE & \\
\cline { 2 - 5 } & $0.000118^{*}$ & $0.000330^{*}$ & $-1.00 \mathrm{e}-05$ & 0.000249 \\
\hline \multirow{2}{*}{ EPS } & $(6.44 \mathrm{e}-05)$ & $(0.000178)$ & $(4.34 \mathrm{e}-05)$ & $(0.000200)$ \\
\hline \multirow{2}{*}{ LEV } & $0.0773^{* * *}$ & -0.0139 & $0.0528^{* * *}$ & $3.00 \mathrm{e}-05$ \\
\cline { 2 - 5 } & $(0.00380)$ & $(0.0103)$ & $(0.00214)$ & $(0.00980)$ \\
\hline \multirow{2}{*}{ Degree } & $-0.169^{* * *}$ & -0.0106 & $-0.0827^{* * *}$ & -0.0264 \\
\cline { 2 - 5 } & $(0.00827)$ & $(0.0226)$ & $(0.00634)$ & $(0.0292)$ \\
\cline { 2 - 5 } & & -0.0199 & 0.00170 & -0.00630 \\
\hline
\end{tabular}


End of Table 4

\begin{tabular}{|l|c|c|c|c|}
\hline \multirow{2}{*}{ AGE } & $(1)$ & $(2)$ & $(3)$ & $(4)$ \\
\hline \multirow{2}{*}{ LNTA } & $-0.0458^{* * *}$ & -0.0261 & -0.00187 & -0.0522 \\
\cline { 2 - 5 } & $(0.0173)$ & $(0.0502)$ & $(0.00891)$ & $(0.0415)$ \\
\hline \multirow{2}{*}{ LNEMP } & 0.000668 & 0.00447 & -0.00155 & -0.00740 \\
\cline { 2 - 5 } & $(0.00203)$ & $(0.00565)$ & $(0.00139)$ & $(0.00667)$ \\
\cline { 2 - 5 } NDIR & $-0.00495^{* *}$ & $-0.0137^{* *}$ & -0.00171 & $-0.0134^{* *}$ \\
\hline \multirow{2}{*}{ Dual } & $(0.00229)$ & $(0.00634)$ & $(0.00141)$ & $(0.00659)$ \\
\cline { 2 - 5 } & -0.00127 & 0.00382 & 0.000794 & -0.00145 \\
\hline \multirow{2}{*}{ Fage } & $(0.00158)$ & $(0.00440)$ & $(0.00102)$ & $(0.00483)$ \\
\cline { 2 - 5 } & & -0.00964 & -0.00383 & 0.0183 \\
\hline Industry $y_{\text {dummy }}$ & & $(0.0207)$ & $(0.00369)$ & $(0.0173)$ \\
\hline Year ${ }_{\text {dummy }}$ & YES & $-0.00518^{* * *}$ & $0.000776^{* * *}$ & $-0.00687^{* * *}$ \\
\hline \multirow{2}{*}{ Constant } & YES & $(0.00136)$ & $(0.000297)$ & $(0.00141)$ \\
\hline & 0.0710 & YES & YES & YES \\
\hline Observations & $(0.0478)$ & $(0.133)$ & YES & YES \\
\hline R-squared & 4,911 & 4,644 & $(0.0316)$ & $(0.151)$ \\
\hline
\end{tabular}

Hierarchical CEO succession intensity (HCSINT) is positively significant for SOEs while insignificant for non-SOEs (see Table 4).

Table 5 has revealed that hierarchical CEO succession mitigates the cash holdings decisively, which supports the fourth hypothesis H2a. Further, this result elucidates that the appointee CEO via hierarchical succession concentrates on enhancing the performance, so they endorse to hold less cash. Meanwhile, SOE is highly positive significant, which illustrates that SOE endorses cash holdings. Similarly, the number of directors, number of employees and firm age are highly significant, which elaborates that old firms tend to hold cash for future investment. Still, sometimes it allows the CEOs to indulge in agency cost, which is why hierarchical CEO successor orientates to reduce the cash holdings and concentrate on another type of activity (either to invest in R\&D).

Table 5. 2sls instrumental regression (hierarchical CEO succession and cash holdings)

\begin{tabular}{|c|c|c|c|c|}
\hline & $(1)$ & $(2)$ & $(3)$ & $(4)$ \\
\hline \multirow{2}{*}{ VARIABLES } & LnCash & LnCash2 & LnCash & LnCash2 \\
\hline \multirow{2}{*}{ LHCS } & & & -0.190 & 0.0537 \\
\cline { 2 - 5 } & & & $(0.336)$ & $(0.325)$ \\
\hline \multirow{2}{*}{ MHCS } & & & $-0.183^{* *}$ & $-0.176^{* *}$ \\
\cline { 2 - 5 } & & & $(0.0838)$ & $(0.0841)$ \\
\hline
\end{tabular}


End of Table 5

\begin{tabular}{|c|c|c|c|c|}
\hline & (1) & (2) & (3) & (4) \\
\hline \multirow{2}{*}{ HHCS } & & & $-0.139^{\star}$ & $-0.151^{\star}$ \\
\hline & & & $(0.0800)$ & $(0.0813)$ \\
\hline \multirow{2}{*}{ HCS } & $-0.167^{\star}$ & $-0.148^{\star}$ & & \\
\hline & $(0.0952)$ & $(0.0829)$ & & \\
\hline \multirow{2}{*}{ ROA } & $-0.0501^{\star \star \star}$ & $-0.0557^{\star * *}$ & $-0.0500^{\star * \star}$ & $-0.0558^{* * *}$ \\
\hline & $(0.0132)$ & $(0.0137)$ & $(0.0132)$ & $(0.0137)$ \\
\hline \multirow{2}{*}{ EPS } & $0.154^{\star \star *}$ & $0.140^{\star \star \star}$ & $0.154^{\star \star \star *}$ & $0.141^{\star * *}$ \\
\hline & $(0.0183)$ & $(0.0177)$ & $(0.0183)$ & $(0.0177)$ \\
\hline \multirow{2}{*}{ Dual } & $-0.148^{\star * \star}$ & -0.0299 & $-0.148^{\star \star \star}$ & -0.0301 \\
\hline & $(0.0331)$ & $(0.0330)$ & $(0.0331)$ & $(0.0330)$ \\
\hline \multirow{2}{*}{ LNEMP } & $0.383^{\star * \star}$ & $0.224^{\star * \star}$ & $0.383^{\star * *}$ & $0.224^{* * *}$ \\
\hline & $(0.0111)$ & $(0.0110)$ & $(0.0111)$ & $(0.0110)$ \\
\hline \multirow{2}{*}{ NDIR } & $0.0672^{\star \star \star}$ & $0.0217^{\star * *}$ & $0.0669^{\star * \star}$ & $0.0214^{\star * \star}$ \\
\hline & $(0.00828)$ & $(0.00827)$ & $(0.00828)$ & $(0.00828)$ \\
\hline \multirow{2}{*}{ Agency } & $2.19 \mathrm{e}-07$ & $-8.39 e-07$ & $3.14 \mathrm{e}-07$ & $-4.01 \mathrm{e}-06$ \\
\hline & $(4.67 e-06)$ & $(4.83 \mathrm{e}-06)$ & $(4.67 e-06)$ & $(6.79 \mathrm{e}-05)$ \\
\hline \multirow{2}{*}{ SOE } & $0.178^{\star \star \star}$ & $0.195^{\star * *}$ & $0.177^{\star \star *}$ & $0.195^{\star * *}$ \\
\hline & $(0.0312)$ & $(0.0309)$ & $(0.0312)$ & $(0.0309)$ \\
\hline \multirow{2}{*}{ Fage } & $0.0486^{* * *}$ & $0.0351^{\star * *}$ & $0.0487^{\star * \star}$ & $0.0349^{* * *}$ \\
\hline & $(0.00236)$ & $(0.00232)$ & $(0.00237)$ & $(0.00234)$ \\
\hline Industry $_{\text {dummy }}$ & YES & YES & YES & YES \\
\hline Year $_{\text {dummy }}$ & YES & YES & YES & YES \\
\hline \multirow{2}{*}{ Constant } & $17.97^{\star * *}$ & $17.70^{\star * *}$ & $17.97^{\star * *}$ & $17.70^{* * *}$ \\
\hline & $(0.145)$ & $(0.144)$ & $(0.145)$ & $(0.144)$ \\
\hline Observations & 10,260 & 11,077 & 10,256 & 11,073 \\
\hline R-squared & 0.240 & 0.108 & 0.240 & 0.107 \\
\hline
\end{tabular}

In Table 5, hierarchical CEO successions have reduced the cash holdings (HCS). SOE, NDIR, EPS, Fage, and number of employees are positively significant. In column $3^{\text {rd }}$ and $4^{\text {th }}$ medium and high hierarchical CEO succession (MHCS and HHCS) have also mitigated the cash holdings. Lastly, "Agency" represents the agency cost which has been determined by proxy (operation ratio) (Shah et al., 2019a).

Additionally, Table 5 (column $3^{\text {rd }}$ and $4^{\text {th }}$ ) has also contemplated that medium and high hierarchical CEO succession has reduced the cash holdings satisfying the hypothesis $\mathrm{H} 2 \mathrm{~b}$ and $\mathrm{H} 2 \mathrm{c}$, respectively. Further, it contemplates that whenever medium and low-rank board members are allowed to be a CEO, they concentrate on performance. Empirical results are justified following the existing literature which has unveiled that hierarchical 
CEO succession is necessary for boosting the performance and escalating the firms' innovation (as medium hierarchical CEO succession is conducive for firms' performance and high hierarchical CEO succession mitigates the agency problem) (Shah et al., 2019a; Sarfraz et al., 2019).

\section{Empirical results of interaction term of HCS and earning management}

Following Kim et al. (2016), "Absolute Accruals" have been endorsed as a proxy for measuring earning management. Mathematically,

$$
E M=\left|\frac{A C R_{i t}}{T A_{i t-1}} / C F_{i t} / T A_{i t-1}\right| .
$$

In Equation (13), TA- total assets, $C F$ - Operating Income-Accruals and ACR - accruals. Mathematically, Accruals is defined as

$$
A C R_{i t}=\left(\Delta C A_{i t}-\Delta C L_{i t}\right)-\left(\Delta \operatorname{Cash}_{i t}-\Delta S T D_{i t}+\Delta D E P_{i t}\right) .
$$

In Equation (14), CA - total current Assets, $C L$ - Total Current Liabilities, Cash - Cash and Cash Equivalents, STD - Short term debt and DEP - depreciation and Amortization.

$$
\begin{aligned}
& \text { CashHoldings }_{i, t}=\alpha_{0 . t}+\alpha_{1 i t}\left(\text { HCS }_{i t-1} \times E M_{i t}\right)+\alpha_{2 i t} \text { Dual }_{i t}+ \\
& \alpha_{3 i t} L_{N E M P_{i t}}+\alpha_{4 i t}\left(S O E_{i t} \times E M_{i t}\right)+\alpha_{5 i t} N D I R_{i t}+\alpha_{6 i t} F \operatorname{Se}_{i t}+\varepsilon_{i t} .
\end{aligned}
$$

The Equation (15) represents the panel regression for contemplating the moderating role of earnings management.

In Table 6 ( $1^{\text {st }}$ row), the last hypothesis $\mathrm{H} 3$ has been satisfied. The interaction term of HCS and earning management (EM) is negatively significant, which illustrates that firms which are involved in Hierarchical CEO succession do not prefer to hold cash despite involving earning management. Oppositely, the interaction term of SOE and EM has unveiled the positive results while identifying SOEs involving in earning management do keep the cash holdings excessively.

Table 6. Earning management and cash holdings

\begin{tabular}{|c|c|c|c|c|}
\hline & $(1)$ & $(2)$ & $(3)$ & $(4)$ \\
\hline \multirow{2}{*}{ VARIABLES } & LnCash & LnCash2 & LnCash & LnCash2 \\
\hline \multirow{2}{*}{ EM $\times$ HCS } & $-0.224^{* * *}$ & $-0.155^{* *}$ & & \\
\cline { 2 - 5 } & $(0.0782)$ & $(0.0784)$ & & \\
\hline \multirow{2}{*}{ ROA } & $-0.0496^{* * *}$ & $-0.0540^{* * *}$ & $-0.0528^{* * *}$ & $-0.0569^{* * *}$ \\
\cline { 2 - 5 } & $(0.0132)$ & $(0.0135)$ & $(0.0132)$ & $(0.0137)$ \\
\hline
\end{tabular}


End of Table 6

\begin{tabular}{|c|c|c|c|c|}
\hline & (1) & (2) & (3) & (4) \\
\hline \multirow{2}{*}{ EPS } & $0.151^{\star * *}$ & $0.113^{* * *}$ & $0.155^{\star * *}$ & $0.132^{\star * *}$ \\
\hline & $(0.0195)$ & $(0.0187)$ & $(0.0179)$ & $(0.0174)$ \\
\hline \multirow{2}{*}{ Dual } & $-0.197^{\star * *}$ & -0.0239 & $-0.170^{\star * *}$ & -0.0346 \\
\hline & $(0.0350)$ & $(0.0347)$ & $(0.0317)$ & $(0.0316)$ \\
\hline \multirow{2}{*}{ LNEMP } & $0.370^{\star * *}$ & $0.219^{\star \star \star}$ & $0.367^{\star * *}$ & $0.222^{* * *}$ \\
\hline & $(0.0118)$ & $(0.0116)$ & $(0.0107)$ & $(0.0106)$ \\
\hline \multirow{2}{*}{ NDIR } & $0.0565^{\star \star \star}$ & $0.0171^{\star \star}$ & $0.0651^{* * *}$ & $0.0237^{\star * *}$ \\
\hline & $(0.00873)$ & $(0.00868)$ & $(0.00789)$ & $(0.00788)$ \\
\hline \multirow{2}{*}{ Fage } & $0.0483^{\star \star \star}$ & $0.0325^{\star \star \star}$ & $0.0548^{\star * *}$ & $0.0375^{\star * *}$ \\
\hline & $(0.00241)$ & $(0.00237)$ & $(0.00227)$ & $(0.00222)$ \\
\hline \multirow{2}{*}{ SOE $\times E M$} & & & $0.449^{*}$ & $0.383^{*}$ \\
\hline & & & $(0.266)$ & $(0.231)$ \\
\hline Industry $_{\text {dummy }}$ & YES & YES & YES & YES \\
\hline Year $_{\text {dummy }}$ & YES & YES & YES & YES \\
\hline \multirow{2}{*}{ Constant } & $18.03^{\star * *}$ & $17.76^{\star \star \star}$ & $18.16^{* * *}$ & $17.75^{\star * *}$ \\
\hline & $(0.157)$ & $(0.156)$ & $(0.142)$ & $(0.139)$ \\
\hline Observations & 9,025 & 9,720 & 11,278 & 12,195 \\
\hline R-squared & 0.217 & 0.086 & 0.222 & 0.094 \\
\hline
\end{tabular}

In Table 6, the interaction term of hierarchical CEO succession and earning management $(\mathrm{HCS} \times \mathrm{EM})$ is negatively significant while the interaction term $\left(\mathrm{SOE}^{\star} \mathrm{EM}\right)$ is positively significant for cash holdings

\section{Discussion}

Competent corporate governance is inevitable for escalating the firms' performance either through competitive advantage or maintaining corporate sustainability. However, the role of the CEO is pivotal, who enforces to execute such strategies which ultimately escalate the firms' performance. Certainly, the incumbent CEOs should prefer to mitigate the agency cost so that the rights of minority shareholders remain secured, which is also conducive for firms' financial health. Meanwhile, CEOs should also concentrate on the economic condition of the organization, which is why they can decide on cash holding, which acts as hedging for the future sudden detrimental condition. Convincingly, CEO succession is an inevitable phenomenon which disrupts every aspect of the organization. So, it is quite significant to comprehend whether the novel CEO successor holds the cash or not? Additionally, a specific type of CEO succession defines as hierarchical CEO succession which has been already contemplated to be positively related with the firms' performance while mitigating the agency cost (Shah et al., 2019a). In this regard, this study has extended the existing literature by demonstrating the effectiveness of hierarchical CEO succession on cash holdings and SOEs 
and Non-SOEs performance. Comprehensively, it has been deduced that hierarchical CEO successors boost the SOEs performance and reduce the cash holdings decisively. Argumentatively, they are appointed through specific types of forceful succession, which is why they are orientated to boost the SOEs performance.

Moreover, they endeavour to reduce the agency cost, so prefer to reduce the cash holdings. Further, the prior study has witnessed that more effective succession has been occurred in SOEs as compared to Non-SOEs (Conyon \& He, 2011) which is why; hierarchical CEO succession has affected the SOEs vigorously. Lastly, despite earning management manoeuvring, hierarchical CEO successor mitigates the cash holdings. Most precisely, our results are significant following the prior literature (Shah et al., 2019a; Sarfaz et al., 2019) and have contributed further to the existing literature.

\section{Conclusions}

Chinese SOEs are alleged for being controlled via excessive surveillance of government intervention, but it has proven to be a blessing in disguise. Firstly, it has been evaluated that hierarchical CEO successions are conducive for SOEs rather than non-SOEs. Additionally, empirically, it has been suggested whenever CEOs is selected via hierarchical successions; medium-level board members should be preferred. Convincingly, it has been recommended that SOEs should choose the middle-aged CEOs to be appointed via medium hierarchical jumps. Lastly, hierarchical CEO succession intensity is significant for SOEs, but its results suggest that neglecting the senior board members during hierarchical CEO succession will mitigate the momentum of firms' performance. Meanwhile, hierarchical CEO successor mitigates the cash holdings, which signifies that their prime objective is to boost the firms' performance rather than to hold the cash. Specifically, the prior study has witnessed that hierarchical CEO successions enhance innovation, mitigate the agency cost. Hence, they endeavor to maintain the firms' performance which is why the hierarchical CEO successors deter the cash holdings so that cash may be utilized among innovative projects.

Further, it has also been evaluated that medium and high hierarchical CEO successions mitigate the cash holding which is also supported by the previous research which has also contemplated the positive impact of medium level hierarchical jump on innovation. Additionally, high hierarchical jumps have been examined to be beneficial for reducing the agency cost, which also supports the empirical results vehemently. Additionally, empirical results have also unveiled that earnings management as moderator also mitigates the cash holdings. Reasonably, hierarchical CEO successors deter the earnings management activity, so the manipulation through earnings management is less effective.

The study has also unveiled the practical implication while recommending that hierarchical CEO succession is a blessing in disguise. It has revealed that medium level or high-level hierarchical CEO successor endorse to mitigate the cash holdings, which ultimately deter the agency cost problem. So, medium hierarchical CEO successor is the best choice for being appointed as a CEO through hierarchical CEO succession. Meanwhile, the moderator earnings management also deters the cash holdings even under the aegis of hierarchical CEO successor, which will ultimately boost the firms' performance. 
Though this study has contributed via the innovative concept of hierarchical CEO succession influencing the cash holdings and firms' performance, even then it has certain limitations. Firstly, hierarchical CEO succession has not evaluated the impact of gender difference which would be interesting research in future. Secondly, the impact of hierarchical CEO succession can also be contemplated for the organizational risk. Lastly, it would be an interesting study to analyze the interacting term of SOEs and Non-SOEs for three types of hierarchical CEO succession among different types of industries separately.

\section{Funding}

The current study was supported by the Chinese National Natural Science Fund under Grant number 70671029, Humanities \& Social Science Project from the Chinese Ministry of Education under Grant 16YJAZH014, Philosophy and Social Science Foundation of Guangdong Province under Grant GD15CGL03

\section{References}

Atif, M., Liu, B., \& Huang, A. (2019). Does board gender diversity affect corporate cash holdings? Journal of Business Finance \& Accounting, 46(7-8), 1003-1029. https://doi.org/10.1111/jbfa.12397

Chang, C.-C., Kato, L.-H., \& Chen, H.-Y. (2018). How does real earning management affect the value of Cash holdings? Comparison between information and agency Perspective. Pacific Basin Finance Journal, 51, 47-64. https:/doi.org/10.1016/j.pacfin.2018.06.001

Cyert, R. M., \& March, J. G. (1963). A behavioral theory of the firm. (pp. 169-187). Prentice-Hall.

Conyon, M. J., \& He, L. (2011). Executive compensation and corporate governance in China. Journal of Corporate Finance, 17(4), 1158-1175. https://doi.org/10.1016/j.jcorpfin.2011.04.006

Daily, C. M., Certo, S. T., \& Dalton, D. R. (2000). International experience in the executive suite: The path to prosperity? Strategic Management Journal, 21(4), 515-523.

https://doi.org/10.1002/(SICI)1097-0266(200004)21:4\%3C515::AID-SMJ92\%3E3.0.CO;2-1

Dittmar, A., Mahrt-Smith, J., \& Servaes, H. (2003). International corporate governance and corporate cash holdings. Journal of Financial and Quantitative analysis, 38(1),111-133. https://doi.org/10.2307/4126766

Fauver, L., Hung, M., Li, X., \& Taboada, A. G. (2017). Board reforms and firm value: Worldwide evidence. Journal of Financial Economics, 125(1), 120-142. https://doi.org/10.1016/j.jfineco.2017.04.010

Hambrick, D. C., \& Mason, P. A. (1984). Upper echelons: The organization as a reflection of its top managers. Academy of Management Review, 9(2), 193-206. DOI: 10.2307/258434

Harford, J., Mansi, S. A., Maxwell, W. F. (2008). Corprorate Governance and firm cash holdings in U.S. Journal of Financial Economics, 87(3), 535-555. https://doi.org/10.1016/j.jfineco.2007.04.002

Hazarika, S., Karpoff, J. M., \& Nahata, R. (2012). Internal corporate governance, CEO turnover, and earnings management. Journal of Financial Economics, 104(1), 44-69.

https://doi.org/10.1016/j.jfineco.2011.10.011

He, J., \& Huang, Z. (2011). Board informal hierarchy and firm financial performance: Exploring a tacit structure guiding boardroom interactions. Academy of Management Journal, 54(6), 1119-1139. https://doi.org/10.5465/amj.2009.0824

Hu, F., \& Leung, S. C. (2012). Top management turnover, firm performance and government control: Evidence from China's listed state-owned enterprises. The International Journal of Accounting, 47(2), 235-262. https://doi.org/10.1016/j.intacc.2012.03.006 
Intintoli, V. J., \& Kahle, K. M. (2016). Cash holdings and CEO turnover. Quarterly Journal of Finance, 6(04), 1650022. https://doi.org/10.1142/S2010139216500221

Iqbal, S., Nawaz, A., \& Ehsan, S. (2019). Financial performance and corporate governance in microfinance: Evidence from Asia. Journal of Asian Economics, 60, 1-13.

https://doi.org/10.1016/j.asieco.2018.10.002

Jarva, H., Kallunki, J. P., \& Livne, G. (2019). Earnings performance measures and CEO turnover: Street versus GAAP earnings. Journal of Corporate Finance, 56, 249-266. https://doi.org/10.1016/j.jcorpfin.2019.02.005

Jiang, F., Huang, J., \& Kim, K. A. (2013). Appointments of outsiders as CEOs, state-owned enterprises, and firm performance: Evidence from China. Pacific-Basin Finance Journal, 23, 49-64. https://doi.org/10.1016/j.pacfin.2013.01.003

Jebran, K., Chen, S., \& Tauni, M. Z. (2019). Principal-principal conflicts and corporate cash holdings: Evidence from China. Research in International Business and Finance, 49, 55-70. https://doi.org/10.1016/j.ribaf.2019.02.010

Kim, I., Miller, S., Wan, H., \& Wang, B. (2016). Drivers behind the monitoring effectiveness of global institutional investors: Evidence from earnings management. Journal of Corporate Finance, 40, 24-46. https://doi.org/10.1016/j.jcorpfin.2016.06.006

Kusnadi, Y. (2019). Political connections and the value of cash holdings. Finance Research Letters, 30, 96-102. https://doi.org/10.1016/j.frl.2019.03.035

Li, H., Hang, Y., Shah, S. G. M., Akram, A., \& Ozturk, I. (2020). Demonstrating the Impact of Cognitive CEO on Firms' Performance and CSR Activity. Frontiers in Psychology, 11. https://doi.org/10.3389/fpsyg.2020.00278

Mobbs, S. (2013). CEOs under fire: The effects of competition from inside directors on forced CEO turnover and CEO compensation. Journal of Financial and Quantitative Analysis, 48(3), 669-698. https://doi.org/10.2139/ssrn.1108438

Page, T. B. (2018). CEO attributes, compensation, and firm value: Evidence from a structural estimation. Journal of Financial Economics, 128(2), 378-401. https://doi.org/10.1016/j.jfineco.2018.02.006

Sarfraz, M., Ozturk, I., Shah, S. G. M., \& Maqbool, A. (2020). Contemplating the impact of moderators agency cost and supervisors on corporate sustainability under the aegis of cognitive CEO. Frontiers in Psychology. https://doi.org/10.3389/fpsyg.2020.00965

Sarfraz, M., Qun, W., Shah, S. G. M., \& Fareed, Z. (2019). Do hierarchical jumps in CEO succession invigorate innovation? Evidence from Chinese economy. Sustainability, 11(7), 2017. https://doi.org/10.3390/su11072017

Shah, S. G. M., Tang, M., Sarfraz, M., \& Fareed, Z. (2019a). The aftermath of CEO succession via hierarchical jumps on firm performance and agency cost: Evidence from Chinese firms. Applied Economics Letters, 26(21), 1744-1748. https://doi.org/10.1080/13504851.2019.1593932

Shah, S. G. M., Sarfraz, M., Fareed, Z., ur Rehman, M. A., Maqbool, A., \& Qureshi, M. A. A. (2019b). Whether CEO succession via hierarchical jumps is detrimental or blessing in disguise? Evidence from Chinese listed firms. Zagreb International Review of Economics and Business, 22(2), 23-41. https://doi.org/10.2478/zireb-2019-0018

Sun, Q., Yung, K., \& Rahman, H. (2012). Earning quality and cash holdings. Accounting and Finance, 52, 543-571. https://doi.org/10.1111/j.1467-629X.2010.00394.x

Wong, T. J. (2016). Corporate governance research on listed firms in China: Institutions, governance and accountability. Foundations and Trends ${ }^{\circledR}$ in Accounting, 9(4), 259-326. https://doi.org/10.1561/1400000039

Wong, Y. J., \& Chen, L. Y. (2018). Does the origin of a succession CEO matter in the market value of innovation? Disentangling the origin of internal CEOs. Canadian Journal of Administrative Sciences, 35(1), 136-145. https://doi.org/10.1002/cjas.1396 
Wu, H., Li, S., Ying, S. X., \& Chen, X. (2018). Politically connected CEOs, firm performance, and CEO pay. Journal of Business Research, 91, 169-180. https://doi.org/10.1016/j.jbusres.2018.06.003

Wu, W., Yang, Y., \& Zhou, S. (2017). Multinational firms and cash holdings: Evidence from China. Finance Research Letters, 20, 184-191. https://doi.org/10.1016/j.frl.2016.09.024

Xu, N., Chen, Q., Xu, Y., \& Chan, K. C. (2016). Political uncertainty and Cash holdings: Evidence from China. Journal of Corporate Finance, 40, 276-295. https://doi.org/10.1016/j.jcorpfin.2016.08.007

$\mathrm{Xu}, \mathrm{X} .$, \& Li, Y. (2018). Local corruption and corporate cash holdings: Sheltering assets or agency conflicts? China Journal of Accounting Research, 11, 307-324. https://doi.org/10.1016/j.cjar.2018.05.001

Zhang, Y., \& Qu, H. (2016). The impact of CEO succession with gender change on firm performance and successor early departure: Evidence from China's publicly listed companies in 1997-2010. Academy of Management Journal, 59(5), 1845-1868. https://doi.org/10.5465/amj.2014.0176

Zhu, J., Ye, K., Tucker, J. W., \& Chan, K. J. C. (2016). Board hierarchy, independent directors, and firm value: Evidence from China. Journal of Corporate Finance, 41, 262-279.

https://doi.org/10.2139/ssrn.2638512 